\title{
The New Face of the Semarang Old City in Millennial Generation's Perspective
}

\author{
Satya Budi Nugraha ${ }^{1, *}$ Husna Fauzia ${ }^{2}$ \\ ${ }^{1}$ Department of Geography, Faculty of Social Sciences, Universitas Negeri Semarang \\ ${ }^{2}$ Public Works Department of Water Resources and Spatial Planning of Central Java Province \\ *Corresponding author. Email: satyabnugraha@mail.unnes.ac.id
}

\begin{abstract}
The Semarang Old City arrangement has a positive influence on increasing the tourist attraction of the area for the community. This study aims to examine the millennial generation's perspective on the impact of the Old City of Semarang arrangement in enhancing the image of the area. Data were collected using an online questionnaire targeting the 11-20 and 21-30 years old group. The data obtained through questionnaires were analyzed using quantitative descriptive methods. The results showed that the millennial generation appreciated the Semarang Old City area's arrangement. This arrangement is proven to be able to improve the image of the area and tourist attractions. This condition also affects economic activity in the area. It further enlivens the atmosphere and strengthens the Semarang Old City area's image as an attractive tourist icon for the millennial generation.
\end{abstract}

Keywords: area arrangement, area image, tourist attraction, Semarang Old City.

\section{INTRODUCTION}

The Old City of Semarang site has been an icon for the image of Semarang for a long time. This area is the forerunner to forming the Semarang City, which has a high historical value and regional uniqueness [1]. In the Old City area, there are various buildings from the colonial era with distinctive architecture. Many original buildings are still standing today, which shows how the quality of the building/building materials was. Some are still functioning for trade and service activities, such as a grilled fish restaurant, a bank office (Bank Mandiri), and a life insurance company office (Jiwasraya). Meanwhile, some other buildings are also abandoned, such as the Marba building and the Marabunta building.

The Kota Lama Semarang site had experienced gloomy times, where some of the buildings were neglected, neglected, and abandoned by their owners. The cause is tidal flooding that often occurs in the area, so that people are reluctant to use existing buildings for activities. In addition, the Kota Lama Semarang area has also been affected by fires, floods, and land subsidence [2]. As a result, some of the buildings were used by homeless people. Meanwhile, some other areas became prone to crime due to the dark conditions/lack of lighting.
Since 2018, the Semarang City Government has made arrangements for the Old City Site, especially the Kota Benteng site. The central Government's funding supports this project through the Ministry of Public Works and Spatial Planning. This arrangement aims to realize the city of Semarang as a livable and sustainable heritage city and improve the tourism sector [3]. The Government's focus in structuring the Old City of Semarang Site is to build public facilities to support increased economic activity through investment. The development budget allocation supports public facilities, such as roads, channels, lights, street furniture, and others [4].

The spatial planning implemented by the Government in the Old City of Semarang area is a form of urban renewal. Urban Renewal is not a program that changes everything wrong by breaking it down and building a new one. However, this program puts forward various alternatives to restore the face of a blurry area for the better [5]-[7]. It can be done by various methods, such as modernization, rehabilitation, cleaning, or rebuilding [7]-[10]. In general, the main objective of the urban renewal program is to improve the entire environment by improving the damaged area, improving the traffic situation, and providing public open space and better urban infrastructure. It includes 
developing social and economic aspects through job creation [11]-[13].

This study aims to examine the millennial generation's perspective on the impact of the Old City of Semarang arrangement in enhancing the image of the area. This research is interesting because spatial planning in an area can change the image of the area. The image of an area is a mental image of an area following the average views of the people. Lynch (1960) emphasizes the importance of residents' impressions of the city. He suggests that a clear image can provide many things that are very important to the community. A city's emotional legitimacy and imageability is an impression that arises on the physical quality of an area or environment [14].

\section{RESEARCH METHOD}

The research was conducted in the Old City of Semarang area, precisely at the Kota Benteng site (Figure 1). This area is included in Tanjung Mas Sub District (North Semarang District) and Purwodinatan Sub District (Central Semarang District). The area is covering \pm 25.277 hectares (ha). Physically, this area is bordered by Jalan Merak to the north; Kali Semarang,
Jalan Kampung Sleko, and the rail line to the west; Jalan Sendowo in the south; and Jalan Cenderawasih to the east [15].

The target of this study is the community age group 11-20 years and 21-30 years. The data was collected by distributing random online questionnaires. The questionnaire was prepared using Google Form. Researchers distributed the online questionnaire randomly in July-August 2020. The questionnaire was intended for people who had visited or traveled in the Old City of Semarang area after the Semarang City Government's structuring. The total data obtained were 48 respondents. Furthermore, the data obtained through questionnaires were analyzed using quantitative descriptive methods.

Aspects of the assessment that were asked of the target community groups were those related to improving the image of the Kota Lama Semarang area after restructuring was carried out, which included: (1) Improved organization of various events, (2) Increased tourist attraction, (3) Improved security and order, (4) Increased comfort of circumstances, and (5) Strengthening the area's image as a tourist icon of Semarang.

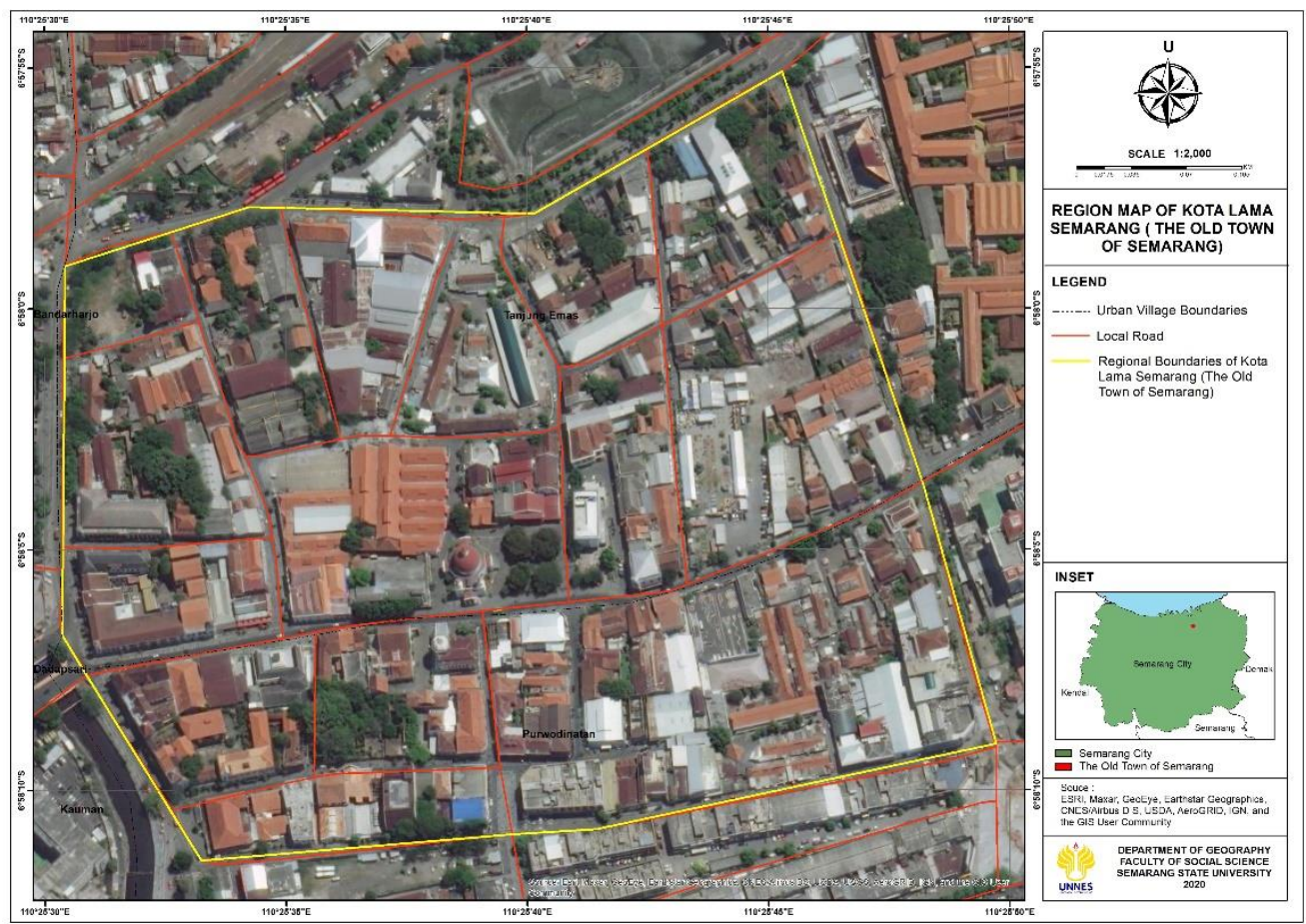

Figure 1. Image Map of Aerial Photographs of the Old City of Semarang 


\section{RESULT AND DISCUSSION}

Based on the results of the data recap from the questionnaire (Figure 2), information was obtained that 24 people $(50 \%)$ strongly agreed and 23 people $(48 \%)$ agreed with the increase in organizing events in the Kota Lama Semarang area due to an image change. In addition, in the second aspect, 12 people (25\%) strongly agree, and 36 people $(75 \%)$ agree that there has been an increase in tourist attractions after the arrangement. The Semarang City Government regularly holds the Kota Lama Festival. This event is an effort to revive activities in the Kota Lama area. By organizing this event, it is hoped to trigger local and out-of-town tourists, even from abroad.

In addition, tourist attractions that appear in the Kota Lama Semarang area include location spots for photos (selfies or group selfies). Some ancient buildings have their charm to be used as photo backgrounds. Meanwhile, at certain times (Friday, Saturday, and Sunday evenings), many street artists registered with the Semarang City Culture and Tourism Office display artistic attractions in various parts of the Kota Lama Semarang area. These attractions then become an attraction for the millennial generation (Figure 3).

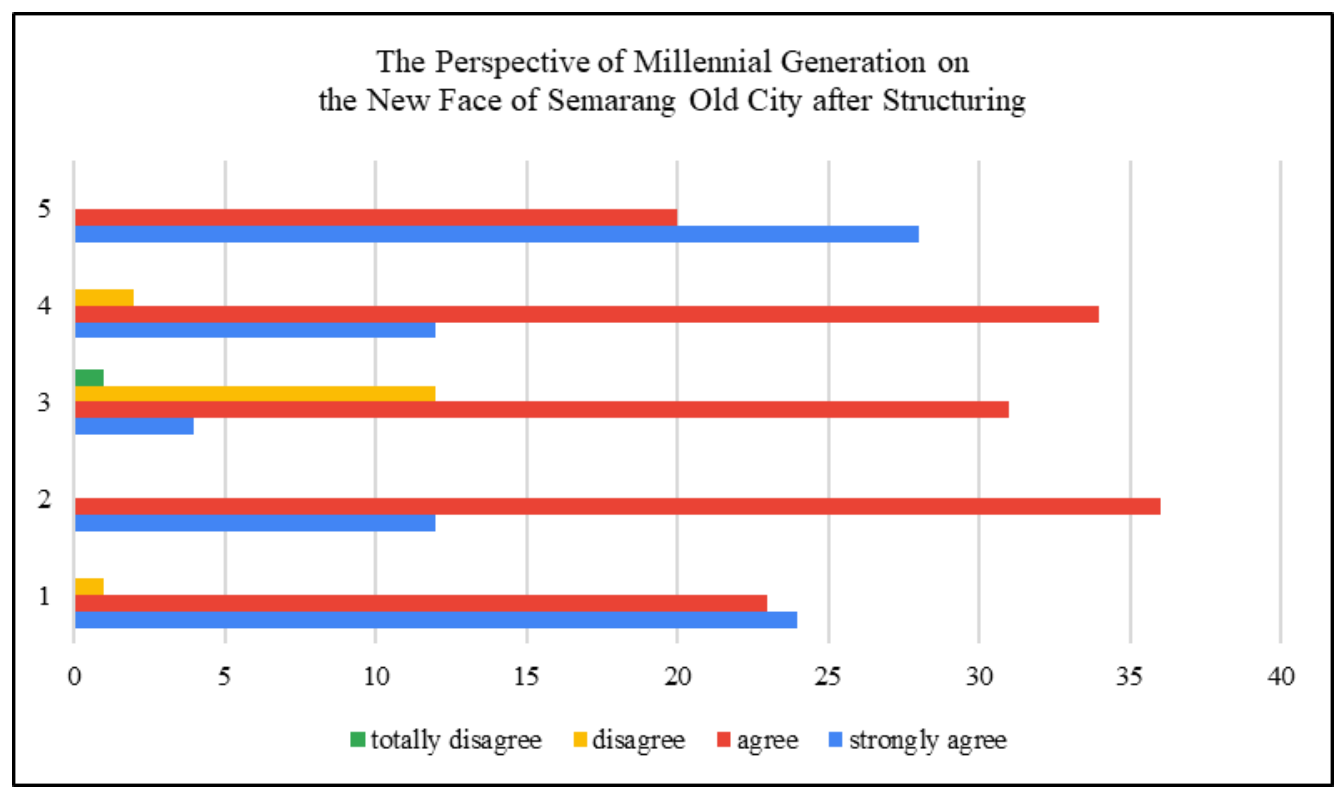

(note: (1) Improved organization of various events, (2) Increased tourist attraction, (3) Improved security and order, (4) Increased comfort of circumstances, and (5) Strengthening the area's image as a tourist icon of Semarang)

Figure 2. A representative diagram of the perceptions of the millennial generation on the new face of the Old City of Semarang

The millennial generation group also has a good view of changing security and order conditions and comfort. The arrangement of the Old City of Semarang area has proven to create a safer and more orderly environmental condition. According to the respondent's opinion, four people (8\%) strongly agree, and 31 people $(65 \%)$ agree that security and order have improved after restructuring and revitalizing activities in the area. Good security and order conditions can create a good impression on visitors, so they do not hesitate to return to visit. Although, there are still some respondents who have the opposite opinion, namely 12 people $(25 \%)$ who disagree and one person (2\%) strongly disagree with changes in the security and order aspects. They think that there are still illegal charges made by a group of people, especially at vehicle parking locations. Besides, there are still pickpocketing crimes in busy activities. Of course, it needs to be considered by the Government These actions can be taken by controlling the parking location and conducting continuous security patrols during certain events.

In addition to security and order factors, the Old City of Semarang area arrangement can also create a comfortable situation and condition. The majority of respondents support this. A total of 12 people (25\%) strongly agreed, and 34 people $(71 \%)$ agreed that the comfort of the situation and conditions in Semarang City had increased after the reorganization. The provision of public facilities such as park benches, lighting, good pedestrians is some examples of area arrangements that have succeeded in supporting the realization of a comfortable situation and conditions in the Old City of Semarang area. 


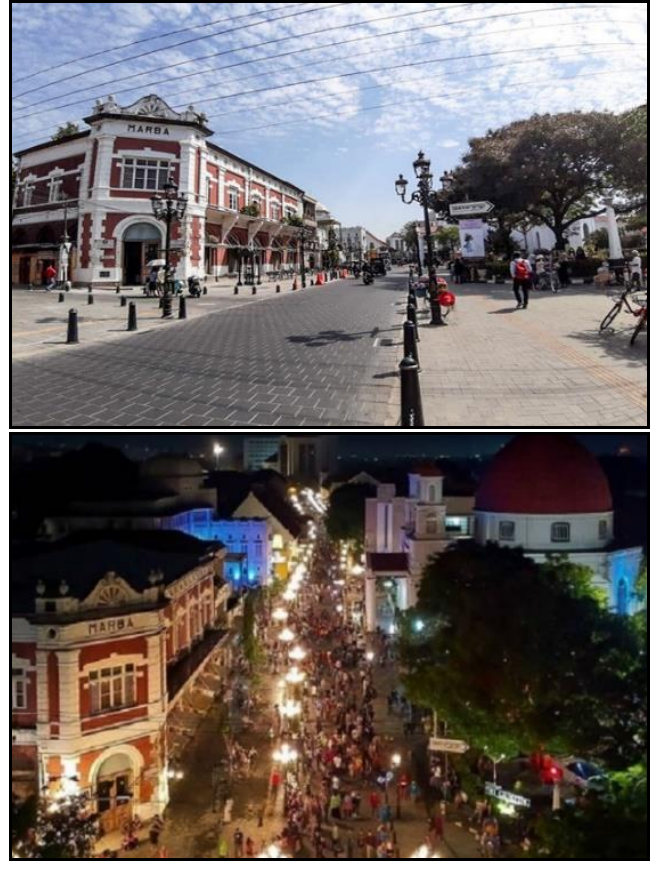

Figure 3. Alternative Photo Spot and Attractions of the Semarang Old City Festival

Applying the urban renewal concept in the Semarang Old City Area arrangement is a gradual and sustainable effort. This structuring program has proven to be able to create a new atmosphere that is considered more comfortable. Moreover, by reviving tourism activities in the area, it has increased economic activities that support tourism. Respondents' statements support changes in the image of the area formed after the arrangement of the Kota Lama Semarang area for the better. Twenty-eight people (58\%) strongly agree, and 20 people (42\%) agree that the Semarang Old City Area arrangement can change and strengthen the image of the area as a tourist icon of the city of Semarang.

The optimistic view of the millennial generation on improving the image of the Old City of Semarang area is a product of advances in information technology. It means that with the increasingly open flow of digital information from around the world, millennials have more references to tourist sites based on ancient buildings. Through literacy knowledge about Old City tourism in other cities or countries, of course, this millennial generation has tremendous enthusiasm for the existence of similar objects in their cities. In other words, this positive perspective is also a form of appreciation to the Government, which has succeeded in arranging the Old City of Semarang area from being quite attractive to becoming better and very interesting to visit.

\section{CONCLUSION}

Most of the millennial generation (93\%) give a positive impression of the Semarang Old City arrangement. The increase in organizing events and tourist attractions has attracted the millennial generation to visit. Although, there are still some millennial generations $(27 \%)$ who think that the arrangement of the Semarang Old City has not succeeded in improving security and order in the area. However, in general, the image of the Semarang Old City area is getting better after the arrangement. Therefore, promotions to increase the popularity of the Old City of Semarang area as a prime city tourism destination should be continued.

\section{AUTHORS' CONTRIBUTIONS}

Satya Budi Nugraha, as the first author, is responsible for compiling the draft and analyzing the research data. Husna Fauzia, as the second author, is responsible for conducting a literature review to complete the introduction part and support analysis of the results.

\section{ACKNOWLEDGMENTS}

The author would like to thank all those who have supported this research. This research received funding support from the Faculty of Social Sciences, Universitas Negeri Semarang.

\section{REFERENCES}

[1] P. K. Dewi, A. Antariksa, and S. Surjono, "Pelestarian Kawasan Eks Pusat Kota Kolonial Lama Semarang (Preservation of the Former Old Colonial City Center Area of Semarang)," Arsitektur, vol. 1, no. 3, pp. 145-156, 2008.

[2] B. T. Susanti, Y. T. N. Dewi, and Y. T. Sunarimahingsih, Pengembangan Strategi Pengurangan Resiko Bencana untuk Kawasan Kota Lama Semarang (Development of Disaster Risk Reduction Strategies for the Kota Lama Semarang area). Semarang, 2018.

[3] H. B. Alexander, “'Creative Hub', Penataan Lanjutan Kota Lama Semarang (Further Arrangement of the Old City of Semarang)," http://properti.kompas.com, 2019. .

[4] A. Rismoko, "Penataan Kawasan Kota Lama Diperluas (Expanded Old City Area Arrangement)," http://ayosemarang.com, 2019. .

[5] P. O. Adekola, D. Azuh, D. Adeloye, and E. Amoo, "Urban renewal in Nigeria: a slash and burn approach?," Environ. Dev. Sustain., vol. 21, no. 5, pp. 2165-2182, 2019, DOI: 10.1007/s10668-0180130-2. 
[6] M. Bonneville, "The ambiguity of urban renewal in France: Between continuity and rupture," J. Hous. Built Environ., vol. 20, no. 3, pp. 229-242, 2005, DOI: $10.1007 / \mathrm{s} 10901-005-9012-7$.

[7] Y. Yung (Simon) and L. Chan, "To rehabilitate or redevelop? A study of the decision criteria for urban regeneration projects," J. Place Manag. Dev., vol. 1, no. 3, pp. 272-291, 2008, DOI: $10.1108 / 17538330810911262$.

[8] C. Di Domenico and M. Di Domenico, "Heritage and urban renewal in Dundee: Learning from the past when planning for the future of a postindustrial city," J. Retail Leis. Prop., vol. 6, no. 4, pp. 327-339, 2007, DOI: 10.1057/palgrave.rlp.5100074.

[9] R. Donaldson, D. du Plessis, M. Spocter, and R. Massey, "The South African area-based urban renewal programme: Experiences from Cape Town," J. Hous. Built Environ., vol. 28, no. 4, pp. 629-638, 2013, DOI: 10.1007/s10901-013-9348-3.

[10] C. kiu Cheung and K. Kwok Leung, "Social Mitigation of the Impact of Urban Renewal on Residents' Morale," Soc. Indic. Res., vol. 106, no. 3, pp. 523-543, 2012, DOI: 10.1007/s11205-0119820-y.

[11] F. K. W. Wong, E. C. M. Hui, J. T. Y. Wong, and J. K. M. Wan, "The impact of urban renewal to the labour force in Hong Kong," Facilities, vol. 28, no. 13, pp. 611-640, 2010, DOI: $10.1108 / 02632771011083676$.

[12] L. Arvan and D. Nickerson, "Private investment, public aid and endogenous divergence in the evolution of urban neighborhoods," J. Real Estate Financ. Econ., vol. 32, no. 1, pp. 83-100, 2006, DOI: $10.1007 / \mathrm{s} 11146-005-5179-7$.

[13] M. Benkő and T. Germán, "Crime prevention aspects of public space renewal in Budapest," $J$. Place Manag. Dev., vol. 9, no. 2, pp. 191-209, 2016, DOI: 10.1108/JPMD-09-2015-0034.

[14] K. Lynch, The image of the city, vol. 11. MIT Press, 1960.

[15] Pemerintah Kota Semarang, Peraturan Daerah Kota Semarang Nomor 2 Tahun 2020 tentang Rencana Tata Bangunan dan Lingkungan Situs Kota Lama (Semarang City Regional Regulation Number 2 of 2020 concerning Old City Building and Environmental Site Plans). Indonesia, 2020. 